\title{
INTERAKSI DAN HARMONI UMAT BERAGAMA
}

\author{
Joko Tri Haryanto \\ Balitbang Agama Semarang \\ e-mail: jejakagama@yahoo.co.id
}

\begin{abstract}
The community of Singkawang constituted the multi cultural society, in religion, ethnic, and culture. Historically Singkawang society was able to maintain inter religious harmony. The associative social interaction seemed to be potential to support the harmony in the society. Based on the paradigm of functional-structural, society was assumed as an organic system having inter-relatednes between one organ and another in order to maintain the existence of the society. Social interaction within Singkawang society was developed by the the interaction in the cyrcle of family, neighbourhood, economical activities, religious leaders, and the relation within culture and tradition. Inspite of this the relation between the element of society is still cosmopolitant, on which the society members are less active in developing community harmony.
\end{abstract}

Masyarakat Singkawang adalah masyarakat yang terdiri atas berbagai kelompok suku bangsa dan agama. Secara historis, masyarakat Singkawang mampu mempertahankan harmoni antar agama. Model interaksi sosial yang bersifat asosiatif tampaknya potensial untuk mendukung harmoni di dalam masyarakat. Berdasarkan paradigma fungsional-struktural, masyarakat diasumsikan sebagai sistem organik yang memiliki huungan antar bagiannya untuk mempertahankan masyarakat. Interaksi sosial di dalam masyarakat Singkawang dikembangkan melalui interaksi di dalam lingkup keluarga, lingkungan sekitar, aktifitas ekonomi, para pimpinan agama, dan hubungan di dalam lingkup budaya dan tradisi. Meskipun demikian, hubungan antar unsur masyarakat masih kosmopolitan, yang di dalamnya anggota masyarakat kurang aktif dalam mengembangkan harmoni masyarakat.

Keywords: interaksi sosial, harmoni, Singkawang, kosmopolitan 


\section{A. Pendahuluan}

Pembangunan di bidang agama yang diemban oleh Kementerian Agama, ditunjukkan dalam visi Kementerian Agama yaitu "Terwujudnya masyarakat Indonesia taat beragama, rukun, cerdas, mandiri dan sejahtera lahir batin". Untuk mencapai visi tersebut, salah satu misi Kementerian Agama adalah meningkatkan kualitas kerukunan umat beragama. Kerukunan umat beragama merupakan salah satu pilar penting bagi terwujudnya kerukunan, ketahanan dan kesatuan nasional. Oleh sebab itu, salah satu fokus pembangunan bidang agama adalah upaya mewujudkan dan meningkatkan kerukunan baik intra maupun antar umat beragama.

Pemerintah melalui Kementerian Agama telah melakukan berbagai kegiatan yang ditujukan untuk mengembangkan kerukunan umat beragama di Indonesia, di antaranya kegiatan reharmonisasi dan antisipasi disharmonisasi kehidupan sosial keagamaan daerah pascakonflik/rawan konflik; penguatan peran dan pemberdayaan nilai-nilai kearifan lokal; peningkatan pemahaman agama berwawasan multikultural; pengembangan budaya damai; Participatory Action Research (PAR) untuk pengembangan model kerukunan; pemberdayaan organisasi keagamaan; serta penguatan peran tokoh-tokoh agama dan pemuka agama. Selain itu juga peningkatan kerukunan umat beragama juga dilakukan melalui penerbitan, sosialisasi dan implementasi Peraturan Bersama Menteri Agama dan Menteri Dalam Negeri Nomor 9 dan 8 Tahun 2006 tentang Pedoman Pelaksanaan Tugas Kepala Daerah/Wakil Kepala Daerah dalam Pemeliharaan Kerukunan Umat Beragama, Pemberdayaan Forum Kerukunan Umat Beragama, dan Pendirian Rumah Ibadah.

Terlepas dari upaya pemerintah meningkatkan kualitas kerukunan beragama tersebut, di sisi lain masyarakat sendiri juga memiliki peran yang penting dalam menjaga kerukunan antar umat beragama. Bangsa Indonesia yang memiliki norma-norma kemasyarakatan yang di antaranya bersumber pada nilai-nilai agama mendukung terciptanya kerukunan di lingkungan mereka. Nilai-nilai agama mendorong umat penganutnya untuk cinta damai, membangun kerjasama, sikap toleransi dan menghormati agama lain. Ajaranajaran inilah yang sebenarnya menjadi landasan sikap dan perilaku masyarakat secara umum dalam berinteraksi dan berhubungan dengan orang lain yang menganut agama berbeda. Kerukunan merupakan nilai yang uni- 
versal, yang dapat ditemukan dalam setiap ajaran agama. Setiap agama mengajarkan kepada umatnya untuk mengasihi sesama makhluk hidup dan bersikap positif terhadap alam. ${ }^{1}$ Semua agama pada hakikatnya mengajarkan umatnya untuk mawas diri, mengenal dirinya terlebih dahulu, mengenal segala musuh yang ada dalam dirinya serta kelobaan, iri hati, kemarahan dan lain sebagainya. Dengan senantiasa mawas diri, umat beragama akan tetap dapat menjaga saling pengertian dengan umat lain dan benar-benar dapat mengembangkan wawasan kebangsaan, menyadari diri sebagai bagian dari bangsa Indonesia yang besar. ${ }^{2}$

Itu sebabnya masyarakat Indonesia secara umum mampu menunjukkan diri sebagai masyarakat yang memiliki toleransi terhadap umat agama lainnya. Selain itu, diperlukan pula kesadaran umat beragama dalam menumbuhkan sikap toleran dalam kehidupan beragama. Sikap toleran ini dapat menumbuhkan rasa saling menghargai dan saling menghormati antara satu dengan yang lain untuk mewujudkan ketenteraman dan perdamaian. Perwujudan sikap toleransi dalam beragama dapat dicirikan dengan beberapa indikasi. Indikator-indikator sikap toleransi tersebut adalah adanya penerimaan terhadap kelompok lain untuk hidup bersama, terciptanya ruang dialog antar umat beragama, dan saling menghargai terhadap aktivitas keberagamaan pemeluk agama lain. ${ }^{3}$

Salah satu wilayah yang masyarakatnya memiliki toleransi tinggi terhadap perbedaan agama, sehingga tercipta kerukunan antar umat beragama adalah kota Singkawang di Provinsi Kalimantan Barat. Kota Singkawang meskipun memiliki pluralitas agama maupun etnis, tetapi tidak pernah terjadi konflik fisik yang disebabkan faktor agama maupun etnis. Pada saat kasus kerusuhan di Sambas dan Sampit akibat konflik antara etnis Dayak dan Melayu dengan etnis Madura, di mana kerusuhan tersebut menjalar ke berbagai kota lainnya, kota Singkawang tidak ikut mengalami kerusuhan. Bahkan banyak warga etnis Madura yang mendapatkan perlindungan di Singkawang.

\footnotetext{
${ }^{1}$ Tanja, Victor YT, Pluralisme Agama dan Problem Sosial, (Jakarta: Pustaka Cidesindo, 1998), h. xx.

2 Dharmika, Ida Bagus, Kerukunan Umat Beragama, Studi Kasus di Subak Air Sumbul Bali dalam Bingkai Sosial Kultural, Seri 2. (Jakarta: Badan Litbang Agama, 1997), h. 43.

3 Kartanegara, Mulyadhi. "Islam dan Multikulturalisme: Sebuah Cermin Sejarah". dalam Baidhawy, Zakiyuddin (ed.), Reinvensi Islam Multikultura, (Surakarta: PSB UMS, 2005), h. 207-210.
} 
Masyarakat Singkawang yang sebagian besar dari etnis Tionghoa, Melayu, dan Dayak, serta sebagian besar warga beragama Islam, Budha dan Katolik, ternyata mampu menjaga kerukunan etnoreligius. Secara fisik, banyak bangunan tempat ibadah di kota Singkawang ini yang saling saling berdampingan, seperti gereja di samping klenteng, atau masjid yang berada dekat dengan klenteng atau gereja, tetapi tidak pernah ada konflik antar umat pemeluknya. Kerukunan umat beragama di kota Singkawang tersebut menunjukkan terjadinya interaksi sosial yang positif dari warganya. Keadaan ini sangat menarik untuk diteliti dan dideskripsikan pola kerukunan antar umat beragama di Singkawang yang multikultural tersebut. Penelitian ini memberi gambaran tentang interaksi sosial masyarakat yang menjadi pilar bagi kerukunan antar umat beragama di kota Singkawang, yang diharapkan dapat menjadi pembelajaran bagi pengembangan kerukunan antar umat beragama di daerah-daerah lain.

Pluralitas masyarakat Singkawang, terutama dalam agama dan budaya etnis ternyata tidak menimbulkan persoalan bagi kerukunan umat beragama. Hal ini karena masyaraat Singkawang menjalankan interaksi sosial yang cenderung assosiatif. Bahkan dalam hal tradisi budaya dan tradisi agama dalam masyarakat Singkawang mampu menjadi kohesi sosial. Oleh karena itu sangat penting untuk mengetahui, bagaimana interaksi sosial dalam dinamika kerukunan masyarakat di Kota Singkawang, dan bagaimana relasi agama dan budaya dalam kerukunan masyarakat di Kota Singkawang

Penelitian ini dilaksanakan bulan Maret 2010 di Kota Singkawang Provinsi Kalimantan Barat. Lokasi ini dipilih dengan pertimbangan bahwa Kota Singkawang telah dikenal sebagai daerah yang cukup aman dan damai. Hal ini terbukti pada waktu terjadinya kerusuhan etnik tahun 1999 yang melibatkan etnis Dayak, Melayu dan Madura di beberapa daerah di Kalimantan Barat, seperti Sambas, Bengkayang, Sanggau Ledo dan sebagainya, Kota Singkawang tidak mengalami kerusuhan, bahkan Kota Singkawang menjadi salah satu tempat pengungsian bagi warga Madura. ${ }^{4}$ Selain itu, di Kota Singkawang juga terdapat tiga etnis besar yang hidup berdampingan dengan damai dan rukun, yaitu etnis Tionghoa, Melayu dan Dayak, di samping etnis lainnya. Keber-

4 Ali, Mursyid (ed.), Pemetaan Kerukunan Kehidupan Beragama di Berbagai Daerah di Indonesia. Jakarta: Puslitbang Kehidupan Keagamaan Badan Litbang dan Diklat Departemen Agama, 2009), h. 49. 
adaan etnis Tionghoa, di daerah lain terutama di Jawa sering menjadi sasaran kecemburuan sosial, tetapi di Singkawang hal tersebut tidak menjadi masalah sosial.

Pendekatan sosiologis dalam penelitian ini menggunakan perspektif fungsionalisme struktural. Asumsi dasar Fungsionalisme sruktural diantaranya adalah bahwa masyarakat haruslah dilihat sebagai suatu sistem yang tersusun dari bagian-bagian yang saling berhubungan satu sama lain, dan saling pengaruh mempengaruhi antarbagian tersebut secara ganda dan timbal balik. Pandangan Fungsionalisme struktural terhadap integrasi, bahwa sekalipun integrasi sosial tidak pernah tercapai dengan sempurna, tetapi secara fundamental bergerak ke arah equilibrium yang bersifat dinamis. ${ }^{5}$ Pendekatan ini dipergunakan untuk melihat masyarakat Singkawang yang majemuk terintegrasi melalui proses interaksi sosial. Interaksi sosial dalam masyarakat Singkawang membentuk kerukunan umat beragama, antara interaksi yang assosiatif maupun dissosiatif secara dinamis menuju kondisi equilibrium tersebut.

Penelitian ini termasuk dalam penelitian kualitatif, yakni penelitian yang ditujukan untuk menghasilkan data berupa kata-kata tertulis atau lisan dari orang-orang-orang yang diamati. ${ }^{6}$ Jenis penelitian ini adalah penelitian kasus yaitu penelitian yang bertujuan untuk mempelajari secara intensif mengenai unit sosial tertentu meliputi individu, kelompok, atau lembaga. ${ }^{7}$ Guna mendapatkan data-data bagi penelitian ini, maka pengumpulan data dilakukan dengan teknik observasi, wawancara dan dokumentasi. Dari hasil pengumpulan data tersebut, kemudian dilakukan analisis dengan analisis deskriptif yang dilakukan melalui tahapan reduksi data, penyajian data, dan menarik kesimpulan. ${ }^{8}$

\section{B. Kondisi Sosio-Religius Masyarakat Singkawang}

Kota Singkawang di Provinsi Kalimantan Barat termasuk kota kecil dengan luas 50.400 ha, yang dibagi menjadi 5 (lima) wilayah kecamatan

${ }^{5}$ Nasikun, Sistem Sosial Indonesia, (Jakarta: Rajawali Press, 1992), h. 11-12.

${ }^{6}$ Moleong, Lexy J., Metode Penelitian Kualitatif, (Bandung: Rosda Karya, 2000), h. 4.

7 Zuriah, Nurul, Metodologi Penelitian Sosial dan Pendidikan Teori-Aplikasi, (Jakarta: Bumi Aksara, 2006), h. 48.

${ }^{8}$ Moleong, Metode Penelitian Kualitatif, h. 36. 
meliputi 26 kelurahan. Nama Singkawang menurut versi Melayu diambil dari nama tanaman 'Tengkawang' yang terdapat di wilayah hutan tropis. Namun yang paling diyakini adalah versi bahasa Cina, Singkawang berasal dari kosa kata 'San Keuw Jong' yang secara harfiah berarti Gunung Mulut Lautan, maksudnya suatu tempat yang terletak di kaki gunung menghadap ke laut. ${ }^{9}$ Penamaan demikian dilakukan oleh para pedagang dan penambang emas dari Monterado. Para penambang dan pedagang yang kebanyakan berasal dari negeri China, sebelum mereka menuju Monterado terlebih dahulu beristirahat di Singkawang, dan menjadikannya sebagai tempat transit pengangkutan hasil tambang emas (serbuk emas). Nama San Keuw Jong menunjukkan kondisi feng sui daerah yang positif, dan perkembangan wilayah Singkawang ini memang dinilai oleh mereka cukup menjanjikan, sehingga antara penambang tersebut beralih profesi ada yang menjadi petani dan pedagang di Singkawang. ${ }^{10}$

Pascakemerdekaan wilayah Singkawang menjadi bagian dari Kabupaten Sambas bahkan menjadi lokasi ibukota kabupaten Sambas di Singkawang (UU No. 27 Tahun 1959) dengan status Kecamatan Singkawang. Pada tahun 1981 Kota ini menjadi Kota Administratif Singkawang (PP No. 49 Tahun 1981). Singkawang menjadi Daerah Otonom berdasarkan Undang-Undang Nomor: 12 Tahun 2001 tentang Pembentukan Kota Singkawang.

Kehidupan masyarakat Kota Singkawang yang multietnis terdiri dari 3 (tiga) etnis terbesar yakni Tionghoa (Cina), Melayu dan Dayak ditambah suku-suku lainnya yang hidup secara berdampingan dan harmonis. Berdasarkan data Dinas Kependudukan dan Catatan Sipil Kota Singkawang pada tahun 2008, tercatat sebanyak 198.907 jiwa, mayoritas penduduk adalah suku Tionghoa dari subsuku Hakka/Khek sekitar $62 \%{ }^{11}$ atau $42 \%$ selebihnya dari suku Melayu, Dayak, Jawa, dan lainnya. ${ }^{12}$ Di Singkawang selain sukusuku tersebut juga ada pendatang dari berbagai daerah lainnya seperti Madura, Sumatera, Sulawesi, Ambon dan sebagainya. Sedangkan data Dinas Kependudukan dan Catatan Sipil Kota Singkawang, keadaan bulan Februari 2010 menunjukkan populasi penduduk Singkawang telah mencapai 211.448

\footnotetext{
${ }^{9} \mathrm{http} / / /$ www.singkawang.us

${ }^{10} \mathrm{http}: / /$ www.singkawangkota.go.id

${ }^{11} \mathrm{http} / / /$ id.wikipedia.org/wiki/Kota_Singkawang

${ }^{12} \mathrm{http}: / /$ humas.singkawangkota.go.id
} 
jiwa, tanpa keterangan suku bangsa. ${ }^{13}$ Dari komposisi kesukuan tersebut, masyarakat Singkawang banyak menggunakan bahasa Hakka atau Khek dan bahasa Melayu atau Indonesia.

Adapun komposisi penduduk berdasarkan agama adalah masyarakat yang memeluk agama Islam sebanyak 102.907 jiwa atau 48,66\%; disusul agama Budha yang dianut oleh 81.346 jiwa atau 38,47\%; agama Katolik dianut oleh 16.292 jiwa atau 7,7\%; agama Kristen 9.624 jiwa atau 4,55\%; agama Hindu 123 jiwa atau 0,05\%; dan agama lainnya sebanyak 1.156 jiwa atau $0,54 \%{ }^{14}$ Pemetaan pemeluk agama di Kota Singkawang adalah kecamatan yang mayoritas umat Islam terdapat di kecamatan Singkawang Tengah yang mencapai 75,14\% dan Kecamatan Singkawang Utara 81,4\%. Penduduk mayoras Katolik berada di Kecamatan Singkawang Timur yang mencapai 35\%. Penduduk mayoritas Budha terdapat di Kecamatan Singkawang Barat sebanyak 58,13\% dan Kecamatan Singkawang Selatan $52,82 \% .15$

Kehidupan keagamaan di Kota Singkawang selama ini telah terbina dengan baik. Hal ini terlihat dari tempat-tempat ibadah yang tersebar di sudut-sudut kota singkawang. Menurut data Kantor Kementerian Agama Kota Singkawang, jumlah tempat ibadah di Singkawang meliput: 109 buah masjid, 63 gereja Katolik, 13 gereja Kristen, 69 vihara dan 270 klenteng. Oleh karena masyarakat banyak terkonsentrasi di wilayah pusat perkotaan, maka tempat-tempat ibadah ini banyak di pusat kota dan bahkan beberapa di antaranya berdiri berdampingan, terutama klenteng dengan tempat ibadah lainnya, baik masjid ataupun gereja. Walaupun tempat ibadah ini berdiri berdampingan, di kota Singkawang hampir tidak ada masalah dengan peribadatan masing-masing agama.

Aktivitas masyarakat Singkawang dalam memenuhi kebutuhan hidup mereka di bidang perekonomian terutama di sektor perdagangan. Sektor perdagangan ini lebih banyak dilakukan oleh warga Tionghoa, bahkan sampai 90\% perdagangan dikuasai oleh etnis Tionghoa dari sembako hingga alat-alat

${ }^{13}$ Dinas Kependudukan dan Catatan Sipil 2010

${ }^{14}$ Dinas Kependudukan dan Catatan Sipil 2010. Keterangan dari pegawai Dispencapil, bahwa agama lainnya adalah agama Khonghucu, karena dalam sistem SIAK belum terdapat kolom agama Khonghucu.

${ }^{15}$ Dinas Kependudukan dan Catatan Sipil 2010 
elektronik dan jasa. Selain itu etnis Tionghoa banyak juga yang bekerja di sektor lainnya seperti pertanian, perkebunan dan nelayan. Sedangkan etnis lainnya, hanya bagian kecil yang bergerak di bidang perdagangan dan terutama di daerah-daerah pinggiran yang merupakan bagian dari komunitas etnisnya sendiri. Etnis Melayu lebih banyak bergerak di pemerintahan menjadi pegawai negeri dan menjadi petani, serta sebagian lagi begerak di sektor perdagangan, terutama makanan yakni dengan membuka warung makan. Sedangkan etnis Dayak lebih banyak bergerak di sektor pertanian, dan sebagian lainnya di bidang perdagangan dan pemerintahan. Perkembangan politik melalui reformasi dan demokratisasi telah membuka peluang etnis Tionghoa untuk berkiprah di dunia politik dan pemerintahan. Bahkan sekarang ini walikota Singkawang adalah Karman Hasan yang berasal dari etnis Tionghoa dan wakilnya dari etnis Melayu.

Secara umum kesenjangan ekonomi antaretnis tidak terlalu mencolok di Singkawang. Di kota yang sebagian besar etnis Tionghoa ini, warga dari etnis Tionghoa tidak semuanya berkemampuan ekonomi tinggi, banyak juga warga etnis Tionghoa yang juga termasuk warga miskin. Banyak di antara mereka yang melakukan pekerjaan kasar seperti menjadi petani penggarap, buruh bangunan, karyawan, dan nelayan. Hal ini juga sama terjadi di etnis yang lain, di mana strata ekonomi warga etnis Melayu dan Dayak ada yang kaya dan ada pula yang miskin. Kecilnya kesenjangan ekonomi ini menjadikan sentimen antaretnis dalam bidang perekonomian tidak terlalu besar. Dengan demikian oleh karena keadaan perekonomian yang relatif hampir sama antar etnis, maka itu juga terjadi dalam hubungannya dengan strata ekonomi pemeluk agama.

\section{Interaksi dalam Dinamika Kerukunan di Singkawang}

\section{a. Pertetanggaan dan Keluarga}

Masyarakat Singkawang terdiri atas warga yang beragam, baik etnis maupun agama. Dalam suatu wilayah kelurahan hampir semua etnis dan agama ada di dalamnya. Namun demikian, ada kecenderungan warga Singkawang saling mengelompok terutama berdasarkan etnisnya dalam suatu lingkungan desa. Suatu wilayah terbatas, seperti lingkup Rukun Tetangga (RT) umumnya didominasi oleh kelompok etnis tertentu, sehingga ada 
wilayah yang mayoritas etnis Tionghoa, ada yang mayoritas Melayu atau Dayak. Orang-orang dalam satu wilayah atau warga saling berhubungan satu sama lain dengan baik, meskipun beda etnis maupun beda agama. Hubungan antaranggota warga atau pertetanggaan yang didasari oleh persamaan atau perbedaan agama tidak menonjol, dibandingkan faktor budaya etnis. Latar belakang etnis sangat berpengaruh dalam mendasari budaya atau perilaku umum warga yang saling tetangga tersebut.

Hal yang sangat terlihat nyata adalah penggunaan bahasa untuk saling berhubungan. Dalam masyarakat yang mayoritas dihuni oleh etnis Tionghoa di Singkawang lebih banyak menggunakan bahasa Tionghoa dengan dialek Khek. Warga etnis Melayu, Dayak, bahkan Jawa banyak yang mampu berbahasa Khek secara aktif untuk berkomunikasi dengan warga Tionghoa. Sementara yang bagi warga Tionghoa yang sudah tua banyak yang tidak bisa atau kurang lancar berbahasa lain selain bahasa Khek. Penggunaan bahasa Khek tersebut oleh etnis yang dianggap "lebih pribumi" menunjukkan adanya bentuk akomodasi warga Singkawang terhadap upaya hidup bersama dalam satu lingkungan dengan etnis Tionghoa.

Namun hal sebaliknya tidak berjalan dengan baik, di mana etis Tionghoa seperti diakui beberapa narasumber dari etnis Tionghoa sendiri maupun dari etnis lain, bahwa banyak warga Tionghoa, terutama yang berusia tua, atau yang berpendidikan rendah, cenderung membatasi berhubungan dengan sesama etnis mereka sendiri. Akibatnya warga etnis Tionghoa dipandang sebagai warga yang tertutup, ekslusif, dan kurang ramah oleh warga etnis lain. Hal ini berbeda dengan etnis Melayu, Dayak dan Jawa yang cenderung terbuka, termasuk memulai berkomunikasi apabila bertemu jalan. ${ }^{16}$

Namun, pada warga Tionghoa yang masih muda pada umumnya dapat bergaul secara terbuka dengan warga lain etnis. ${ }^{17} \mathrm{Hal}$ ini nampaknya terkait dengan situasi politik masa sekarang, dimana warga Tionghoa tidak lagi merasa mendapat tekanan yang berbeda dengan situasi saat orang-orang tua Tionghoa mengalaminya di era Orde Baru. Terlebih lagi, warga Tionghoa sering menjadi korban perampokan, dibanding warga etnis lain sehingga mereka mudah curiga terhadap orang asing. ${ }^{18}$

${ }^{16}$ Anggapan ini diungkapkan oleh informan yang dari Melayu, H. Mastur dan Yanto. Hal yang sama tetapi juga dibenarkan oleh informan dari Tionghoa, Piong Sunarto, Budiman, dan Edi Darlius.

17 Wawancara dengan Pdt. Jap Jiu Siu, dan Sun Jin, pengurus majelis agama Budha Maetriya.

18 Wawancara dengan Budiman, dan Edi Darlius. 
Hubungan pertetanggaan antara warga yang seagama, tidak berbeda dengan hubungan antarawarga yang berbeda agama. Mereka saling menyapa untuk menanyakan keperluan atau saling berbagi kabar apabila bertemu. Pada saat hari raya, umumnya mereka juga saling berkirim makanan terutama kue-kue dengan tetangga yang dipandang dekat. ${ }^{19}$ Kegiatan kerjasama untuk saling membantu lebih sering berjalan secara tidak formal, terutama antar tetangga yang berdekatan rumahnya. Sedangkan kerjasama secara formal yang melibatkan banyak orang dalam satu wilayah umumnya dikoordinasikan oleh lembaga warga seperti ketua RT.20

Interaksi pertetanggaan lebih dikarenakan hubungan sewilayahan saja. Di mana mereka berada dalam suatu wilayah secara bersama-sama, dan kurang memiliki ikatan kepentingan bersama dalam wilayah tersebut, kecuali kebutuhan tempat tinggal dan mencari penghasilan. Namun demikian kebutuhan untuk menjadikan lingkungan atau wilayah hidup mereka dapat aman dan tenteram, mereka saling berupaya menerima perbedaan-perbedaan di antara mereka. Upaya akomodasi ini merupakan hal yang paling utama dalam hubungan pertetanggaan di masyarakat Singkawang.

Termasuk penggunaan bahasa Khek secara luas oleh masyarakat Singkawang, termasuk oleh etnis lain yang dianggap "lebih pribumi," menunjukkan adanya interaksi akomodatif dari masyarakat untuk hidup bersama. Akomodasi menunjuk pada usaha-usaha untuk meredakan suatu pertentangan atau hal yang dapat menimbulkan pertentangan untuk mencapai kestabilan dengan berusaha untuk tidak saling mengganggu dengan cara mencegah, mengurangi atau menghentikan ketegangan yang akan timbul atau yang sudah ada. ${ }^{21}$ interaksi Akomodatif ini sangat mendukung situasi kerukunan di Kota Singkawang.

Namun demikian, hubungan pertetanggaan antaretnis semacam ini memungkinkan munculnya prasangka-prasangka sosial (social prejudice), seperti yang terjadi pada warga Tionghoa yang dipandang tertutup, ekslusif dan kurang ramah. Terlebih juga karena ketidak mampuan dan kemauan sebagian warga Tionghoa berkomunikasi selain bahasa Khek. Prasangka

19 Wawancara dengan H. Mastur, Bon Cin Nen, dan Pdt. Matius Mao.

20 Wawancara dengan H. Mastur.

21 Taneko, Soleman. B. Struktur dan Proses Sosial..., h. 124; Soekanto, Suryono, Sosiologi Suatu Pengantar, (Jakarta: Raja Grafindo, 1995) h. 83; Hendropuspito, Sosiologi Sistematik, (Yogyakarta: Kanisius, 1989), h. 231. 
sosial (social prejudice) terjadi karena: (a) kurang pengetahuan dan pengertian akan hidup pihak lain; (b) kepentingan perseorangan atau golongan; (c) ketidakinsyafan akan kerugian yang dialami masing-masing kalau prasangka ini dipupuk..$^{22}$ Akibat adanya prasangka sosial ini akan mudah terjadi kesalahpahaman terhadap tindakan pihak lain yang mempengaruhi interaksi di antara mereka. Hubungannya dengan kerukunan di masyarakat, situasi tersebut menjadikan kohesi sosial (daya rekat sosial) menjadi berkurang. Dengan demikian dapat berpotensi terjadinya interaksi yang dissosiatif di masyarakat.

Hubungan yang lebih erat di masyarakat adalah hubungan keluarga. Di Kota Singkawang juga terjadi pernikahan antaretnik dan antaragama, misalnya warga etnik Tionghoa yang menikah dengan etnik lain, pemeluk agama satu dengan pemeluk agama lainnnya. ${ }^{23}$ Pada umumnya, pernikahan antaragama berujung pada konversi agama karena tuntutan agama agar pernikahan berada dalam agama yang sama dan juga administrasi negara agar perkawinan dilakukan dalam bimbingan oleh pemuka agama. Terutama apabila salah satu dari pasangan itu Islam, maka akan berkonversi ke Islam. ${ }^{24}$ Pada beberapa kasus konversi ini menimbulkan ketegangan dengan keluarga, tetapi umumnya setelah sekian waktu akan ada pemulihan kembali. ${ }^{25}$ Dengan amalgamasi ini, maka pasangan suami istri akan masuk dalam lingkungan budaya etnis atau agama tertentu.

Pernikahan campuran ini menunjukkan adanya interaksi asmilasi antar warga yang sekain merekatkan hubungan satu kelompok keluarga kepada keluarga yang lain. Dengan demikian kohesi sosial menjadi semakin kuat dan mendukung terciptanya kerukunan di masyarakat. Terlebih pada beberapa keluaga Tionghoa dan Dayak yang masih mempertahankan pola kehidupan keluarga besar, di mana seluruh keluarga dari nenek, ayah-ibu, anak-menantu

${ }^{22}$ Susanto, Astrid S., Pengantar Sosiologi dan Perubahan Sosial, (Jakarta: Binacipta, 1985) h. 105.

${ }^{23}$ Wawancara dengan H. Mastur, Edi Darlius, dan H. Herman.

24 Wawancara dengan H. Mastur, Ketua FKUB dan Sekretaris MUI Singkawang; Edi Darlius seorang tokoh MABT; dan H. Herman, ketua PITI Singkawang. PITI adalah Persaudaraan Imam Tauhid Indonesia, salah satu organisasi yang dibentuk sebagai perhimpunan dan pembinaan bagi muslim Tionghoa terutama muallaf. Di singkawang anggota PITI menurut H. Herman mencapai lebih kurang 5000-an, tetapi yang aktif mungkin hanya 200-an saja. Muallaf di Singkawang Menurut H. Herman dalam satu tahunnya mencapai 100-an orang baik dari Tionghoa, Dayak maupun etnis lain.

${ }^{25}$ Wawancara H. Herman dan Edi Darlius. 
hingga cucu hidup dalam satu rumah atau lingkungan. Hal ini semakin meningkatkan pengetahuan dan penghormatan terhadap perbedaan agama.

\section{b. Pelanggan, Karyawan dan Majikan}

Masyarakat Singkawang yang berbeda agama saling berinteraksi dalam bentuk akomodasi, yang pada umumnya sebagai konsekuensi logis dari perbedaan-perbedaan pilihan hidupnya melalui penyesuaian diri terhadap eksistensi pihak lain. Dalam bidang ekonomi, hubungan antar warga yang berbeda agama maupun berbeda etnis bertemu dalam aktivitas ekonomi. Terjadinya hubungan antara pembeli dan penjual dalam sistem pasar memungkinkan interaksi antar umat beragama dalam bidang perekonomian. Pada situasi ini, masing-masing orang berinteraksi sebagai upaya memenuhi kebutuhan hidupnya dengan memanfaatkan kelebihan orang lain. Di Kota Singkawang, penguasaha dan pedagang pada umumnya adalah etnis Tionghoa yang beragama Budha atau Khonghucu, tetapi pembelinya bisa dari etnis Melayu, Dayak atau lainnya yang beragama Islam, atau Kristen.

Dalam bidang perdagangan, di Kota Singkawang hampir 90\% pelakunya adalah etnis Tionghoa. Etnis lainnya hanya sebagian kecil saja, misalnya etnis Melayu umumnya usaha warung makan. Interaksi dalam bidang ekonomi ini dilandasi hukum ekonomi, yaitu mencari keuntungan sebesar-besarnya dengan strategi tertentu. Perdagangan yang dilakukan oleh etnis lain di lingkungan etnis Tionghoa pada akhirnya kalah karena penguasaha Tionghoa berani memberi harga jauh lebih rendah. Hal ini karena pedagang-pedagang Tionghoa mendapatkan harga lebih murah dari distributornya, yang umumnya juga dikuasai oleh etnis Tionghoa juga. Akibatnya perdagangan yang dilakukan oleh etnis lain lebih banyak dilakukan di wilayah pinggiran atau di wilayah yang tidak dikuasai oleh pengusaha Tionghoa. ${ }^{26}$

Namun hal tersebut dibantah Edi Darlius, "Pemahaman orang tentang penguasaan sektor ekonomi oleh orang Cina, itu tidak terlalu tepat. Kerena masing-masing etnis juga memiliki bidang usahanya sendiri-sendiri, memang benar banyak pengusaha yang dari Tionghoa, etapi etnis lain juga banyak yang memiliki bidang usaha di sektor yang berlainan, seperti orang Padang atau Melayu membuka rumah makan. Sebenarnya yang terjadi adalah saling

26 Wawancara dengan H. Mastur danYanto. 
dukung antar-elemen masyarakat. Kalaupun ada warga Tionghoa yang kaya di strata atas dalam bidang ekonomi itu hanya sebagian kecil saja, lebih banyak yang menengah ke bawah."

Dalam melakukan aktivitas ekonomi, pengusaha umumnya merekrut tenaga karyawan. Karyawan yang direkrut umumnya lintas etnis, yakni pengusaha Tionghoa selain merekrut karyawan dari etnis Tionghoa juga dari etnis lain. Demikian juga sebaliknya, banyak rumah makan Melayu yang memperkerjakan karyawan etnis Tionghoa. Perlakukan antara majikan terhadap karyawan, dalam hal sikap umumnya biasanya saja, yakni sama-sama dihargai dan diperlakukan setara dalam hal sikap pergaulan. Namun dalam hal penggajian ternyata ada perbedaan. Penguasan Tionghoa meskipun sama baiknya terhadap semua karyawannya, tetapi dalam memberi gaji atau honor biasanya memberi tambahan tersendiri pada karyawan Tionghoa. Dan hal sebaliknya, majikan etnis Melayu juga lebih memperhatikan pekerjanya yang se-etnis. ${ }^{27}$ Praktek semacam ini sering menimbulkan rasa kecemburuan di kalangan karyawan, tetapi itu sudah menjadi paktek umum hubungan majikan dan karyawan di Singkawang.

\section{c. FKUB Wadah Tokoh Agama}

Kegiatan kerjasama yang dilakukan antar umat beragama di Singkawang yang membentuk kerukunan umat beragama adalah aktivitas organisasi lintas agama yang dibentuk dengan tujuan menjaga kerukunan antar umat beragama, yaitu FKUB (Forum Kerukunan Umat Beragama) Kota Singkawang yang terdiri dari perwakilan tokoh-tokoh agama di Kota Singkawang. FKUB ini menjadi pengikat dan perekat kerukunan antar umat oleh karena mereka menjadi penghubung antaragama atau tokoh agama dengan umatnya dalam membina kerukunan antar umat beragama dan menyelesaikan persoalan-persoalan terkait dengan hubungan antar umat beragama seperti pembangunan tempat ibadah. Di FKUB dalam menyelesaikan masalah selalu menggunakan musyawarah sehingga bisa memuaskan semua pihak. Karena itu dalam pengambilan keputusan tidak pernah dilakukan voting. Bagi anggoata FKUB, kunci menjaga kerukunan, pembinaan kerukunan tidak dapat dilakukan sesaat tetapi harus rutin.

27 Wawancara dengan Yanto dan H. Mastur. 
Melalui wadah FKUB inilah lapisan elit umat beragama berinteraksi. Komunikasi antartokoh agama yang terjalin dengan baik dan intens sangat bepengaruh pada kerukunan umat beragama. Terlebih dengan adanya FKUB, pertemuan antar perwakilan tokoh agama ini berjalan dengan rutin, komunikasi berjalan rutin. Komunikasi antartokoh inilah yang kemudian dilanjutkan ke masing-masing umatnya. Dengan demikian Komunikasi lintas agama-lintas adat terjadi dengan sendirinya, karena umumnya tokoh agama banyak pula yang menjadi tokoh adat. Jadi kalau pertemuan di satu majelis agama, pasti juga melibatkan anggota yang dari etnis yang berbeda, begitu juga kalau di majelis agama anggotanya ada yang dari etnis yang berbeda. ${ }^{28}$

Dengan demikian FKUB di Singkawang memainkan peran sebagai perantara antar umat dalam mengkomunikasikan persoalan hubungan antar umat beragama. Peran ini dapat dilakukan karena tokoh-tokoh di FKUB umumnya adalah tokoh masyarakat yang sudah dikenal oleh masyarakat dan merupakan tokoh agama yang memliki akses kepada umatnya masingmasing. Namun sekaligus, sebagai lembaga bentukan pemerintah FKUB cenderung menjadi lemah tanpa subsidi yang cukup dari pemerintah. Di Singkawang, dana untuk kegiatan FKUB hanya tiga juta rupiah untuk satu tahun yang disalurkan melalui bidang Kesra Pemerintah Kota Singkawang. ${ }^{29}$ Akibatnya FKUB kurang mampu bergerak sampai di level bawah.

\section{d. Pertemuan di Ruang Budaya}

Salah satu bentuk nyata interaksi berupa akomodasi adalah adanya toleransi antar warga termasuk toleransi umat beragama. Hal ini ditunjukkan dengan toleransi terhadap keberadaan tradisi dan budaya etnis dan agama untuk dijalankan oleh warga kota Singkawang yang menganutnya. Toleransi ini terlihat dari perayaan-perayaan keagamaan dan adat yang berlangsung di Kota Singkawang. Warga Tionghoa di Singkawang baik yang beragama Budha maupun Khonghucu dapat melaksanakan tradisi Imlek dan Cap Go Meh, serta tradisi lainnya secara terbuka dan bahkan menjadi daya tarik wisatawan.

${ }^{28}$ Wawancara dengan H. Mastur (FKUB Muslim), Bon Cin Nen (FKUB Budha) dan Pdt Matius Mao (FKUB Kristen).

${ }^{29}$ Wawancara dengan H. Mastur. 
Demikian pula kegiatan bagi umat Islam seperti pengajian, maulidan, maupun peringatan hari besar Islam lainnya dapat dijalankan dengan lancar di Singkawang. Bagi umat Nasrani baik yang Katolik ataupun Kristen juga dapat melaksanakan kegiatan Natal maupun peringatan keagamaan lainnya dengan baik. Tradisi adat Dayak seperti Naik Dangau pun diselenggarakan secara besar-besaran di Singkawang. Bahkan di Singkawang dalam beberapa tahun terakhir telah mencatatkan rekor, di antaranya permainan naga terpanjang dan lampu lampion terbesar dalam peringatan Imlek/Cap Go Meh pada 2 tahun terakhir ini, dan pernah pula mencatatkan membuat pohon Natal terbesar. Rencananya rekor yang akan datang adalah membuat ketupat raksasa. ${ }^{30}$

Di Singkawang pembauran antara agama dengan tradisi budaya terjadi, seperti dalam upacara keagamaan katolik, beberapa tarian adat Dayak dijadikan bagian dari upacara keagamaan. ${ }^{31}$ Dalam agama Budha dan Khonghucu bahkan hampir tidak lagi dikenali antara aktivitas tradisi budaya etnis Tionghoa dengan aktvitas keagamaan Budha atau Khonghucu karena antara agama dan budaya ini telah mengalami asimilasi yang sangat kuat. Demikian pula antara tradisi Melayu dengan Islam, di mana Melayu identik dengan Islam menunjukkan adanya asimilasi yang kuat dari budaya Melayu dengan Islam. Namun asimilasi antaragama pada umumnya tidak terjadi. Hal ini karena adanya sifat dogmatik agama.

Persaingan antar umat beragama di Singkawang dalam hal agama misalnya dalam upaya menambah kuantitas pemeluk agama, secara terbuka dan ekspansif belum pernah diketahui. Di Singkawang hampir tidak ada isu-isu tentang kristenisasi atau islamisasi, sebagai upaya yang agresif untuk menambah jumlah penganut. ${ }^{32}$ Adapun persaingan dalam syiar agama, dalam tahun-tahun terakhir ini barangkali mulai muncul dalam bentuk budaya tanding, yakni muncul persaingan dari etnik dan agama lain untuk tampil pula dalam suatu aktivitas budaya yang sama besar. Di satu sisi persaingan ini dapat meningkatkan keragaman budaya dan menambah akivitas budaya masyarakat Singkawang yang dapat semakin menarik minat wisatawan

30 Wawancara dengan Bon Cin Nen dan Pdt. Matius Mao.

31 Wawancara dengan Pdt. Matius Mao, Romulus Sitinjak, Robert.

32 Wawancara dengan H. Mastur dan Pdt. Matius Mao. 
sebagaimana dilakukan masyarakat Singkawang di atas. Namun di sisi lain persaingan ini rawan menjadi konflik.

Persaingan yang positf ini dapat dilihat dari munclnya ide-ide untuk meraih rekor membuat simbol tertentu dalam perayaan hari besar agama. Tahun 2007 di Singkawang warga Tionghoa dan umat Budha atau Khonghucu membuat rekor dengan naga atau liong-liong terpanjang, tahun 2008 umat Nasrani dalam perayaan Natal membuat pohon Natal terbesar, tahun 2009 kemarin di perayaan Imlek dan Cap Go Meh dibuat lampion terbesar, dan rencananya tahun 2010 ini akan dibuat ketupat terbesar. ${ }^{33}$

Pada tahun-tahun sebelum tahun 2009 kegiatan Cap Go Meh telah diterima oleh semua warga Singkawang baik yang etnis Tionghoa maupun lainnya, dan juga umat Budha atau Khonghucu maupun umat agama lainnya sebagai tradisi budaya masyarakat. Dalam perayaan Cap Go Meh di mana diadakan perayaan termasuk mengarak Tatung atau tokoh agama/adat Tionghoa yang menampilkan atraksi "kesaktian," di mana warga dari agama di luar agama Budha atau Khonghucu turut ambil bagian dari kegiatan tersebut dengan motif mendapatkan upah. Namun belakangan ini muncul pandangan bahwa tradisi tersebut sangat lekat dengan etnik dan agama tertentu, sehingga muncul pelarangan dari elit agama atau tokoh agama baik Islam maupun Kristen pada umatnya untuk turut ambil bagian dalam kegiatan tersebut. ${ }^{34} \mathrm{Hal}$ ini ditunjukkan dengan adanya himbauan larangan menjadi tenaga pengangkut Tatung dalam kegiatan Cap Go Meh.

Kegiatan Cap Go Meh yang dipandang sebagai kegiatan keagamaan bagi Etnis Tionghoa ditandingi dengan kegiatan Pawai Akbar dalam rangka Maulud Nabi Muhammad SAW oleh KNPI dan FPI kota SIngkawang. Dua acara yang memobilisasi massa tersebut dikuatirkan oleh banyak pihak dapat menimbulkan konflik dan benturan antarmassa karena diselenggarakan pada hari yang sama. Bahkan dari Kantor Kementerian Agama Kota Singkawang, Majelis Ulama Indonesia (MUI) Kota Singkawang, dan aparat kepolisian tidak mendukung penyelenggaraan pawai tersebut, bukan pada kegiatannya tetapi

\footnotetext{
33 Wawancara dengan Bon Cin Nen, Pdt. Matius Mao dan H. Mastur.

${ }^{34}$ Majelis Ulama Indonesia (MUI) Kota Singkawang mengeluarkan fawa larangan mengikuti acara Mengarak Tatung dalam kegiatan Cap Go Meh. Pihak Gereja Kristen juga mengeluarkan himbauan bagi umatnya untuk tidak mengikuti kegiatan mengarak Tatung karena mengandung unsur kepercayaan. Wawancara dengan H. Matur dan Pdt. Matius Mao.
} 
pada pilihan waktunya yang dapat menimbulkan resiko konflik horisontal. Pihak kepolisian akhirnya mengarahkan pawai akbar tersebut ke luar kota Singkawang untuk menghindari terjadinya bentrokan massa. Peristiwa ini sebenarnya telah menjadi indikasi adanya aktivitas persaingan yang mengarah pada pertentangan agama. ${ }^{35}$

Peristiwa yang lain adalah pembangunan Tugu Naga yang berada di tengah Kota Singkawang, yang oleh FPI dianggap sebagai simbol agama dan etnis tertentu, sehingga dipandang tidak layak dibangun di kota yang juga banyak etnis dan umat agama lainnya. Massa FPI mengadakan demonstrasi untuk menggagalkan pembangunan patung tersebut, dalam pengawasan, tidak hanya kepolisian, tetapi juga warga yang lain seperti warga Dayak yang berjaga-jaga kalau terjadi perusakan atau mengarah ke anarkhis, mereka pasti juga bertindak. Meskipun akhirnya tidak terjadi konflik fisik, tetapi peristiwa ini cukup mengkuatirkan masyarakat hubungannya dengan kerukunan umat beragama. Polemik pembangunan patung naga tersebut ditengarai bersifat politis, yakni berakar pada pilkada Kota Singkawang, sehingga kebijakan walikota Singkawang senantiasa di-counter oleh lawan politiknya termasuk dengan menggunakan isu-isu etnik atau agama seperti dalam pembangunan patung naga ini. ${ }^{36}$

\section{Perkelindanan Agama dan Budaya}

Kecenderungan suatu etnis tertentu berada dalam wilayah tertentu memiliki keterkaitan dengan agama dan kepercayaan yang dianutnya. Suku bangsa Melayu senantiasa mengidentikkan diri sebagai Muslim atau pemeluk agama Islam. Hal ini terkait dengan kesejarahan kerajaan Melayu yang cukup besar dan kuat di wilayah Kalimantan Barat yaitu Kerajaan Sambas dan juga daerah Mempawah. Itu sebabnya etnis Melayu banyak mendiami wilayah yang terangkai dari Mempawah, Bengkayang, hingga Sambas dan memeluk agama Islam. Adapun etnis Tionghoa banyak terdapat di wilayah perkotaan atau Singkawang Tengah, Barat dan Selatan yang merupakan jalur perniagaan Sedangkan suku Dayak lebih banyak di pinggiran kota Singkawang, terutama di wilayah timur. Hal ini terkait juga dengan tradisi atau budaya

35 Wawancara dengan H. Mastur dan H. Herman.

36 Wawancara dengan Edi Darlius, H. Mastur, Romulus Sitinjak. 
agraris masyarakat Dayak yang masih kental, di mana mereka banyak terkonsentrasi di daerah pegunungan atau hutan.

Pemetaan agama dan etnis ini juga memiliki keterkaitan, yakni bahwa masyarakat Melayu adalah pemeluk agama Islam, sedangkan etnis Tionghoa sebagai mana agama yang dibawa oleh leluhurnya kebanyakan memeluk agama Budha dan Khonghucu. Sedangkan agama Khatolik lebih banyak dipeluk oleh suku Dayak. Hal ini berawal dari sejarah misionaris di pedalaman Kalimantan. Selain itu, bahwa ajaran agama Katolik lebih akomodatif terhadap tradisi-tradisi dan budaya masyarakat tradisional seperti Dayak. Namun pemetaan ini bukan pembagian yang tegas, karena banyak juga warga suku Dayak yang memeluk agama Islam, agama Budha, maupun Kristen. Demikian pula banyak etnis Tionghoa yang muallaf atau menjadi Muslim, selain juga ada yang memeluk agama Katolik atau Kristen. Namun bagi warga etnis Melayu, secara tradisi tidak ada ruang untuk keluar dari Islam, karena keluar dari Islam bearti dianggap bukan lagi Melayu. Bahkan sebaliknya, orang yang masuk Islam, akan dianggap sebagai "menjadi Melayu," atau orang-orang dari etnis lain yang diketahui umum mayoritas Islam pun dianggap sebagai "sama Melayu".

Hal tersebut sebagaimana penjelasan Azra ${ }^{37}$ bahwa agama dalam batasbatas tertentu telah menjadi spesifik bagi kelompok etnis atau komunitas yang bersangkutan, tetapi tidak bagi kelompok etnis atau komunitas lainnya. Dalam konteks ini, agama kelihatan cenderung bersifat komunal; terlepas dari persoalan apakah sifat komunal itu indigenous dari sistem dan struktur sosial komunitas itu sendiri atau datang dari luar. Sifat komunal agama tidak hanya bisa dilihat dari sistem kepercayaan atau keimanan, tetapi juga dalam ritual tau peribadatan. Pada tingkat ini agama saling berhimpit (interwoven) dengan sistem dan struktur sosial. Karena itu jika seseorang dari agama yang dianut oleh mayoritas orang dalam komunitasnya berpindah agama, maka seringkali ia harus meninggalkan atau menanggalkan keanggotaannya dalam komunitas.

Namun demikian agama dan budaya dimaksud adalah hasil pemahaman umatnya. Hal ini karena interpretasi masing-masing orang terhadap ajaran agama terkait fenomena tertentu berbeda-beda. Agama dapat kooperatif

${ }^{37}$ Azra, Azyumardi, Agama dalam Keagaman Etnik di Indonesia, (Jakarta: Badan Litbang dan Diklat Agama Departemen Agama, 1998), h. x-xi. 
dengan budaya, manakala pemahaman seseorang terhadap agama bisa terbuka dan bersifat inklusif. Agama kooperatif dengan budaya di antaranya adalah dimensi sosial atau kemasyarakat. Dalam dimensi ini agama mendorong sikap menghormati orang lain, bekerjasama dalam kebaikan, dan tolong menolong. Dorongan untuk bekerjasama dengan orang lain ini memunculkan ekspresi yang positif dalam kehidupan bersama antar umat beragama. Di Singkawang, tradisi Naik Dangau yang diselengarakan oleh etnis Dayak, bagi yang beragama Kristen atau Katolik malah dilakukan misa tersendiri sebelum perayaan naik dangau secara adat Dayak itu sendiri.

Dalam pemahaman agama yang ekslusif, maka agama umumnya mengambil jarak tegas antara agama dengan budaya. Akibatnya, dimensi kemasyarakatan yang mestinya dapat berjalan bersama-sama dapat terdekadensi. Seperti munculnya fenomena "larangan" mengikuti kegiatan Cap Go Meh pada tahun ini, termasuk munculnya pawai tandingan untuk perayaan Cap Go Meh yaitu Pawai Maulud Nabi, karena memandang mengikuti kegiatan perayaan Cap Go Meh berarti mengikuti ibadah agama lain. Akibatnya dalam hal ini, agama menjadi berlawanan atau versus dengan budaya.

Terlebih faktor pemahaman ini berkelindan dengan politik menjadi "ideologi" yang saling bertentangan dengan pemahaman yang lain, maka akan lebih mempertajam terjadinya konflik. Sebagaimana diungkapkan oleh Geertz $^{38}$ adanya perbedaan ideologi yang mendasar karena tidak senang terhadap nilai-nilai kelompok lain, adanya perbedaan kelas, makin meningkatnya mobilitas status yang cenderung memaksakan kontak di antara individu-individu dan kelompok-kelompok, dan makin intensifnya perjuangan politik yang cenderung menguburkan keadaan agama dengan kepentingan politik. Sementara di Singkawang yang terjadi, yakni persaingan Cap Go Meh dengan Pawai Maulud, kontroversi patung naga ditengarai mengandung motif-motif politis. ${ }^{39}$

Persaingan yang ditunjukkan dalam bentuk kegiatan budaya keagamaan di Singkawang tersebut sebenarnya memiliki tujuan eksplisit yang sama, yakni ekspresi keagamaan yang memberi kemeriahan pada masyarakatnya.

38 Geetrz, Clifford, "Konflik dan Integrasi," dalam Roland Robertson, Agama, Analisa dan Interpretasi Sosiologis, terj. A.F. Saifuddin, (Jakarta: Rajawali Press, 1986) h. 207.

39 Wawancara H. Mastur dan Bon Cin Nen. 
Oleh karena itu, persaingan ini memungkinkan terjadi dalam koridor kedamaian. Jadi bahwa tujuan persaingan sangat berperan, yang dikejar bukan pribadi peserta persaingan, melainkan nilai yang telah ditentukan sehingga upaya persaingan dilakukan secara damai atau secara "fair play," artinya selalu menjunjung tinggi batas-batas yang diharuskan. ${ }^{40}$ Dan apabila norma-norma standar dalam masyarakat diabaikan dalam persaingan ini, maka akan bertendensi ke arah pertikaian atau pertentangan. ${ }^{41}$

Agama dan budaya dalam interaksi sosial di satu sisi dapat menjadi perekat kerukunan, tetapi di sisi lain dapat berpotensi melemahkan kerukunan masyarakat tersebut. Agama dan budaya yang saling mendukung kohesi sosial akan meningkatkan kualitas interaksi yang semakin bersifat assosiatif. Namun aspek agama dan budaya yang saling bertolak-belakang, dapat menumbuhkan interaksi yang dissosiatif. Semakin kuat intensitas interaksi assosiatif, maka daya rekat sosial dan kerukunan akan melahirkan kerjasama. Sebaliknya interaksi dissosiatif akan merenggangkan hubungan sosial dan pertentangan bahkan dapat berujung pada terjadinya konflik. ${ }^{42}$

Interaksi sosial yang tidak terkait secara langsung dengan agama, umumnya dapat berlangsung secara alamiah seperti kebutuhan akan tempat tinggal dan perekonomian. Dalam konteks yang tidak ada keterkaitan ini, nampaknya interaksi sosial di Singkawang bersifat "kosmopolitanisme," 43 yakni masyarakat di Singkawang hidup bersama, tetapi interaksi yang positif dan aktif dalam berhubungan terutama membangun kerukunan beragama hampir tidak ada. Oleh karena itu di Singkawang, menjadi rentan atau berpotensi menjadi ketidakrukunan apabila tidak ada upaya yang aktif untuk membangun kerukunan umat beragama.

Sikap toleransi atau interaksi akomodatif dalam masyaakat Singkawang telah terbentuk. Namun dalam kaitannya dengan upaya membangun atau

${ }^{40}$ Hendropuspito, Sosiologi Sistematik..., h. 240.

${ }^{41}$ Taneko, Struktur dan Proses Sosial..., h. 121.

${ }^{42}$ Young, Kimball, "Social Cultures Processes," dalam Selo Sumardjan dan Soelaiman Sumardi, Setangkai Bunga Sosiologi, (Jakarta: FE Universitas Indonesia, 1964), h. 220; Soekanto dalam Taneko, Struktur dan Proses Sosial ..., h.115.

${ }^{43}$ Istilah ini penulis ambil dari istilah Dr. Alwi Shihab (1988: 41) untuk menunjuk suatu realitas di mana aneka ragam agama, ras, budaya, etnis dan bangsa hidup berdampingan di suatu wilayah tetapi interaksi positif antar penduduk, terutama di bidang agama, tidak ada atau sangat minimal. 
mengembangkan kerukunan antar umat beragama, sebagaimana dikemukakan oleh Abdillah $(2001,13)$, diperlukan pengertian toleransi yang positif. Pengertian toleransi ada yang ditafsirkan secara negatif (negative interpretation of tolerance) dan ada yang positif (positive interpretation of tolerance). Penafsiran yang negatif hanya mensyaratkan cukup dengan membiarkan dan tidak menyakiti atau tidak mengganggu orang lain atau kelompok lain. Namun bagi penafsiran yang positif, toleransi tidak cukup hanya membiarkan atau tidak menganggu, tetapi lebih dari itu toleransi membutuhkan bantuan, dorongan, dukungan dan penghargaan terhadap eksistensi orang lain atau kelompok lain. Dengan pengertian yang positif ini, maka kerukunan akan tercapai.

Di samping toleransi, ada satu pengertian lagi yang penting dalam kerukunan umat beragama, yakni pluralisme. Menurut Alwi Shihab (1988, 4142), kerukunan umar beragama tidak cukup dengan sikap toleransi, tetapi perlu satu langkah lagi yaitu pluralisme, yakni pluralisme. Pluralisme yang dimaksud, pluralisme tidak semata-mata menunjuk pada kenyataan adanya kemajemukan, tetapi keterlibatan aktif terhadap kenyataan kemajemukan tersebut. Dengan demikian tiap pemeluk agama dituntut tidak hanya megakui keberadaan dan hal agama lain, tetapi terlibat secara aktif dalam usaha memahami perbedaan dan persamaan guna tercapainya kerukunan hidup bersama di tengah kebhinekaan. Dengan demikian pluralisme bukanlah dalam pengertian kosmopolitanisme, relativisme, ataupun sinkretisme. Toleransi bagi Shihab, baru dipandang sebagai dasar untuk membangun kerukunan, tetapi belum bangunannya itu sendiri. Oleh karena itu pluralisme menjadi bangunan kerukunan beragama itu sendiri, yakni kemauan aktif untuk menerima perbedaan dan membangun kerukunan dalam perbedaan tersebut.

\section{E. Kesimpulan}

Secara umum interaksi sosial di Kota Singkawang mengarah pada bentuk interaksi yang assosiatif, meskipun ada pula potensi yang mengarah pada dissosiatif. Interaksi assositif meliputi akomodasi berupa sikap toleansi yang cukup baik dalam hal kehidupan beragama; asimilasi dalam bentuk asimilasi budaya terutama asimilasi antara agama dan budaya yang mempererat pertalian dua hal tersebut, dan amalgamasi yang mempererat hubungan antar keluarga, di mana interasi budaya dan amalgamasi semakin mempererat kerukunan antar warga terutama antar umat beragama; serta 
kerjasama dalam pelaksanaan kegiatan budaya yang yang mengemas tradisi keagamaan seperti kegiatan Cap Go Meh. Namun demikian interaksi yang dissosiatif juga terjadi di Singkawang, yaitu munculnya persaingan dalam syiar agama yang mengarah pada bentuk pertentang, seperti yang ditunjukkan dalam peristiwa pembangunan patung naga dan pawai Maulud Nabi.

Keterkaitan antara agama dan budaya di Singkawang membentuk pola agama kooperatif budaya, di mana agama mau dan mampu berkelindan saling memperkaya tradisi keagamaan dan budaya masyarakat. Tetapi juga ada pula pola yang membentuk agama versus budaya, di mana pemahaman agama yang cenderung ekslusif tidak bersedia berintegrasi dengan budaya. Akibatnya kerukunan masyarakat yang memiliki tradisi budaya berbeda dan nilai agama yang berbeda dapat terancam. Sementara di aspek kehidupan yang tidak tekait langsung dengan agama, masyarakat Singkawang cenderung bersifat kosmopolitanisme, yaitu bisa menerima keberadaan orang lain tetapi kurang aktif untuk menjalin hubungan kerjasama. Hal ini pun kurang mendukung terbinanya kerukunan umat beragama di Singkawang.

Dengan demikian kota Singkawang termasuk kota yang memiliki tingkat kerukunan tinggi dengan potensi konflik. Oleh karena itu penting untuk meningkatkan dan mengembangkan interaksi assosiatif antar umat beragama sehingga semakin meningkatkan kerukunan beragama di Singkawang. Adapun potensi-potensi konflik harus diantisipasi agar tidak berkembang menjadi konflik yang dapat menggangu kerukunan umat beragama di Singkawang.

Berdasarkan temuan-temuan dalam penelitian ini, maka pemerintah, terutama Kementerian Agama perlu meningkatkan sosialisasi pemahaman keagamaan yang inklusif, terbuka, moderat dan saling bekerjasama pada masyarakat sehingga mendukung upaya aktif mewujudkan kerukunan umat beragama. Pemerintah secara aktif harus turut menfasilitasi kelompokkelompok sosial, budaya dan keagamaan untuk membicarakan agendaagenda kegiatan budaya agar tidak menjadi persaingan yang kurang sehat dan mengarah pada pertentangan atau konflik, tetapi sebaliknya agenda kegiatan budaya tersebut dapat saling mengisi dan mengautkan kerukunan masyarakat, khususnya umat beragama. Tokoh-tokoh agama dan budaya di Singkawang juga perlu untuk menjalin kerjasama antar umat beragama dalam bidang budaya, serta melakukan rekacipta budaya yang mempererat interaksi antar umat beragama. [w] 


\section{BIBLIOGRAFI}

Ali, Mursyid (ed.), Pemetaan Kerukunan Kehidupan Beragama di Berbagai Daerah di Indonesia. Jakarta: Puslitbang Kehidupan Keagamaan Badan Litbang dan Diklat Departemen Agama, 2009.

Susanto, Astrid S., Pengantar Sosiologi dan Perubahan Sosial, Jakarta: Binacipta, 1985.

Azra, Azyumardi, Agama dalam Keagaman Etnik di Indonesia, Jakarta: Badan Litbang dan Diklat Agama Departemen Agama, 1998.

Dharmika, Ida Bagus, Kerukunan Umat Beragama, Studi Kasus di Subak Air Sumbul Bali dalam Bingkai Sosial Kultural, Seri 2, Jakarta: Badan Litbang Agama, 1997.

Geetrz, Clifford, "Konflik dan Integrasi" dalam Roland Robertson, Agama, Analisa dan Interpretasi Sosiologis, terj. A.F. Saifuddin, Jakarta: Rajawali Press, 1986.

Hendropuspito, Sosiologi Sistematik. Yogyakarta: Kanisius,1989.

http://id.wikipedia.org/wiki/Kota_Singkawang diunduh pada tanggal 22 Maret 2010.

http://www.singkawang.us diunduh pada tanggal 22 Maret 2010.

http://www.singkawangkota.go.id diunduh pada tanggal 22 Maret 2010.

http://humas.singkawangkota.go.id diunduh pada tanggal 27 April 2010.

Kartanegara, Mulyadhi, "Islam dan Multikulturalisme: Sebuah Cermin Sejarah," dalam Baidhawy, Zakiyuddin (ed.), Reinvensi Islam Multikultural, Surakarta: PSB UMS, 2005.

Moleong, Lexy J., Metode Penelitian Kualitatif. Bandung: Rosda Karya, 2000.

Nasikun, Sistem Sosial Indonesia, Jakarta: Rajawali Press , 1992.

Peraturan Bersama Menteri Agama dan Menteri Dalam Negeri Nomor 9 dan 8 Tahun 2006 tentang Pedoman Pelaksanaan Tugas Kepala Daerah/Wakil Kepala Daerah dalam Pemeliharaan Kerukunan Umat Beragama, Pemberdayaan Forum Kerukunan Umat Beragama, dan Pendirian Rumah Ibadah. 
Peraturan Menteri Agama (PMA) Tahun 2010 tentang Rencana Strategis Departemen Agama Republik Indonesia Tahun 2010 - 2014.

Soekanto, Suryono, Sosiologi Suatu Pengantar, Jakarta: Raja Grafindo,1982.

Taneko, Soleman. B., Struktur dan Proses Sosial; Suatu Pengantar Sosiologi Pembangunan, Jakarta. CV Rajawali, 1990.

Tanja, Victor YT., Pluralisme Agama dan Problem Sosial. Jakarta: Pustaka Cidesindo, 1998.

Young, Kimball, "Social Cultures Processes," dalam Selo Sumardjan dan Soelaiman Sumardi, Setangkai Bunga Sosiologi. Jakarta: Penerbit Fakultas Ekonomi Universitas Indonesia, 1964.

Zuriah, Nurul, Metodologi Penelitian Sosial dan Pendidikan Teori-Aplikasi, Jakarta: Bumi Aksara, 2006. 